\title{
MOLECULAR KARYOTYPE ANALYSIS AND MAPPING OF HOUSEKEEPING GENES TO CHROMOSOMES OF SELECTED SPECIES COMPLEXES OF LEISHMANIA
}

\author{
CELSO CRUZ TAVARES*; GABRIEL GRIMALDI, Jr. ** \& YARA MARIA TRAUB-CSEKÖ/+
}

\begin{abstract}
Departamento de Bioquímica e Biologia Molecular, **Departamento de Imunologia, Instituto Oswaldo Cruz, Av. Brasil 4365, 21045-900 Rio de Janeiro, RJ, Brasil *Departamento de Biologia Celular e Genética, Instituto de Biologia, Universidade do Estado do Rio Janeiro, Rua São Francisco Xavier 524,

20550-013 Rio de Janeiro, RJ, Brasil
\end{abstract}

The molecular karyotypes for 20 reference strains of species complexes of Leishmania were determined by contour-clamped homogeneous electric field (CHEF) electrophoresis. Determination of number/position of chromosome-sized bands and chromosomal DNA locations of housekeeping genes were the two criteria used for differentiating and classifying the Leishmania species. We have established two gel running conditions for optimal separation of chromosomes, which resolved DNA molecules as large as 2,500 kilobase pairs (kb). Chromosomes were polymorphic in number (22-30) and size (200-2,500 kb) of bands among members of five complexes of Leishmania. Although each stock had a distinct karyotype, in general the differences found between strains and/or species within each complex were not clear enough for parasite identification. However, each group showed a specific number of size-concordant DNA molecules, which allowed distinction among the Leishmania complex parasites. Clear differences between the Old and New world groups of parasites or among some New World Leishmania species were also apparent in relation to the chromosome locations of beta-tubulin genes. Based on these results as well as data from other published studies the potencial of using DNA karyotype for identifying and classifying leishmanial field isolates is discussed.

Key words: Leishmania - chromosome - molecular karyotype - gene localization PFGE: pulsed-field gel electrophoresis

Kinetoplastid protozoan parasites of the genus Leishmania are a biologically diverse group of trypanosomatid causing the various human and animal leishmaniasis. A wide variety of clinical manifestations are associated with different species of Leishmania and many of these parasites are capable of producing a spectrum of disease in their human hosts. Because of their differences in virulence and variable responses to chemotherapeutic agents, correct parasite identification is essential in any clinicopathologic study of leishmaniasis. Parasite characterization and comparison of various Leishmania stocks isolated from humans, reservoir hosts, and sandfly vectors are also of pratical use in descriptive epidemiol-

Grant support: CNPq; PADCT/FINEP; and CAPES (Brazil); and UNDP/World Bank/WHO Special Programme for Research and Training in Tropical Diseases. ${ }^{+}$Corresponding author.

Received 14 May 1992.

Accepted 30 September 1992. ogy and for disease control (Grimaldi et al., 1989; Anon., 1990).

It is possible to identify a stock as belonging to an already known taxon by using discriminant characters, provided that these characters have been shown to be constant and that the reference system is clearly defined. The identification and taxonomy of species of Leishmania traditionally have been based on phenotypic characters such as the clinical manifestations in humans, epidemiological features, and a variety of biological criteria (Lainson \& Shaw, 1987). More precise taxonomic markers for Leishmania have resulted from the application of established molecular, biochemical, and immunological techniques (e. g., isoenzyme electrophoresis, analysis of kinetoplast minicircle DNA heterogeneity, and the use of species-specific monoclonal antibodies or DNA probes) which can be used to identify, in comparison to reference strains, the leishmanial isolates (Rioux, 1986). However, new techniques are constantly being developed, and 
many other intrinsic parasite characteristics are currently being tested. Among the new molecular tools are the chromosome separation techniques using PFGE (Schwartz \& Cantor, 1984; Carle \& Olson, 1984; Chu et al., 1986) which has made possible to establish DNA karyotypes and the genomic organization of parasitic protozoa (Van der Ploeg et al., 1984). Molecular karyotype analysis has demonstrated chromosome size polymorphisms among Leishmania stocks which reveal a high degree of plasticity in the genome of these parasites (Spithill \& Samaras, 1985; Comeau et al., 1986; Scholler et al., 1986; Bishop \& Miles, 1987; Samaras \& Spithill, 1987; Pages et al,, 1989; Bastien et al., 1990). However, there is evidence showing that Leishmania karyotype might be stable, with chromosomal changes occurring only rarely (Giannini et al., 1990). Thus, PFGE is an alternate approach for identifying leishmanial field isolates (Giannini et al., 1986; Dujardin et al., 1989). In order to extend these observations, specific profiles of the chromosomes of 20 reference strains of species complexes of Leishmania were analyzed in this study, using PFGE and appropriate gel running conditions for optimal separation of chromosome-sized DNA. The use of cloned gene probes for locations of housekeeping genes was an additional tool for parasite classification.

\section{MATERIALS AND METHODS}

Parasites examined and in vitro cultivation - All the strains of Leishamania used in this study were the WHO-recommended reference strains (Anon., 1984). Identification of the stocks has been further confirmed in our laboratories by their reactivity with monoclonal antibodies, isoenzyme electrophoresis, and restriction endonuclease fragment patterns of kDNA. A detailed list of these strains is given in the Table. Promastigotes of each strain were grown at $23-24{ }^{\circ} \mathrm{C}$ in Schneider's Drosophila medium (Hendricks et al., 1978), supplemented with $20 \%$ heat-inactivated fetal bovine serum. Parasites in the log phase of growth were harvested by centrifugation $(1,500 \times \mathrm{g}$ for $10 \mathrm{~min}$ at $4{ }^{\circ} \mathrm{C}$ ) and washed twice in buffer containing $75 \mathrm{mM}$ phosphate buffer, $\mathrm{pH} 8.0,65 \mathrm{mM} \mathrm{NaCl}$, and $1 \%$ glucose. The final pellet was used for preparation of samples for PFGE.

Preparation of samples and PFG electrophoresis - Intact chromosomal DNA for PFGE was prepared as described for trypanosomes
(Van der Ploeg et al., 1984), except that each agarose sample plug contained $10^{7}$ promastigotes. Following protease digestion, the agarose plugs were kept in lysis buffer at $4{ }^{\circ} \mathrm{C}$ until use. PFGE was performed by contourclamped homogeneous electric field (CHEF) technique, using either a Pulsaphor electrophoresis unit from Pharmacia-LKB (Uppsala, Sweden), or a CHEF DRII System from BioRad (Richmond, CA, U. S. A.). Gels were run in $0.5 \times$ TBE buffer $(45 \mathrm{mM}$ Tris, $45 \mathrm{mM}$ boric acid, and $1 \mathrm{mM}$ EDTA, pH 8.0) at 12 ${ }^{\circ} \mathrm{C}$. Eletrophoresis was performed as described in the figure legends. The sizes of the Leishmania chromosomal DNA molecules were determined by comparison to yeast (Saccharomyces cerevisae) chromosomes (Bio-Rad) used as size markers. Following electrophoresis, gels were stained with ethidium bromide, prior to photography and processing for hybridization.

Southern blotting and hybridization - The gels were processed for Southern blotting and DNA was transferred from the gel onto nylon membranes (Nytran; Schleicher \& Schuell, Inc., Keene, NH, U. S. A.) as described (Maniatis et al., 1982). The probes tested were the coding sequence for the alfa-tubulin gene of $L$. enriettii (Wirth \& Slater, 1983), which was provided by Dr D. Wirth, Harvard School of Public Health; the beta-tubulin gene of $L$. major (Spithill \& Samaras, 1985) which was obtained from Dr D. McMahon-Pratt, Yale University School of Medicine; and the DHFR-TS (Beverley et al., 1984) and mini-exon (Iovannisci \& Beverley, 1989) genes of $L$. major which was a gift from Dr S. Beverley, Harvard School of Medicine. Cloned DNAs were labeled by the random priming method (Feinberg \& Vogelstein, 1983), using Random Primer Kit (Boehringer Mannheim, Bromma, Sweden). Hybridization of filters to ${ }^{32} \mathrm{P}$ labelled specific probes were performed according to Takeuchi \& Traub-Csekö (1990). Dehybridization was carried out boiling the filters for $30 \mathrm{~min}$ in $0.1 \mathrm{X}$ SSC $(1 \mathrm{X} \mathrm{SSC}$ is $150 \mathrm{mM} \mathrm{NaCl}, 15 \mathrm{mM} \mathrm{Na}$ citrate) $/ 0.5 \%$ sodium dodecyl sulphate.

\section{RESULTS}

Molecular karyotypes - A comparison of molecular karyotypes from 20 reference strains representing selected species complexes of Leishmania (Table) was done by CHEF electrophoresis. All gels were run at $175 \mathrm{~V}$ at 12 ${ }^{\circ} \mathrm{C}$. As shown in Fig. 1, optimal size separa- 


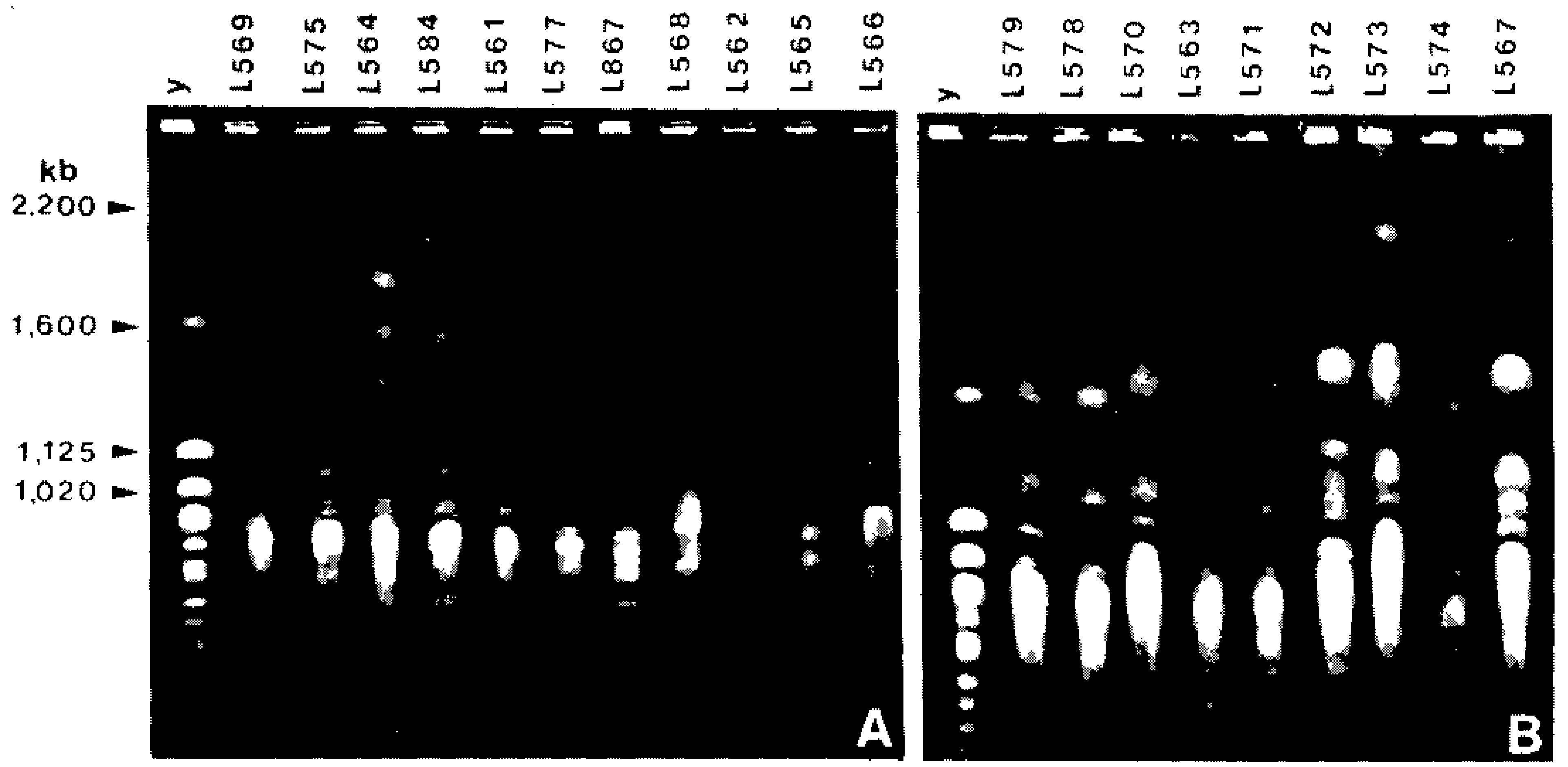

Fig. 1: CIIEF electrophoresis separation in the high size range (above 1,000 kb) of chromosome-sized DNA molecules from reference strains of species complexes of Leishmania. These $1 \%$ agarose gels were run at $175 \mathrm{~V}$ for $24 \mathrm{hr}(\mathrm{A})$ or $30 \mathrm{hr}(\mathrm{B})$, at $12^{\circ} \mathrm{C}$, with a $200-100 \mathrm{~s}$ pulse ramp (using a CIIEF DRII System from BioRad) and then stained with ethidium bromide and photographed under UV transillumination. The stock codes of the strains are indicated above the lanes; information on their origin is given in the Table. The apparent sizes of DNA molecules are estimated relative to yeast chromosomes used as markers.

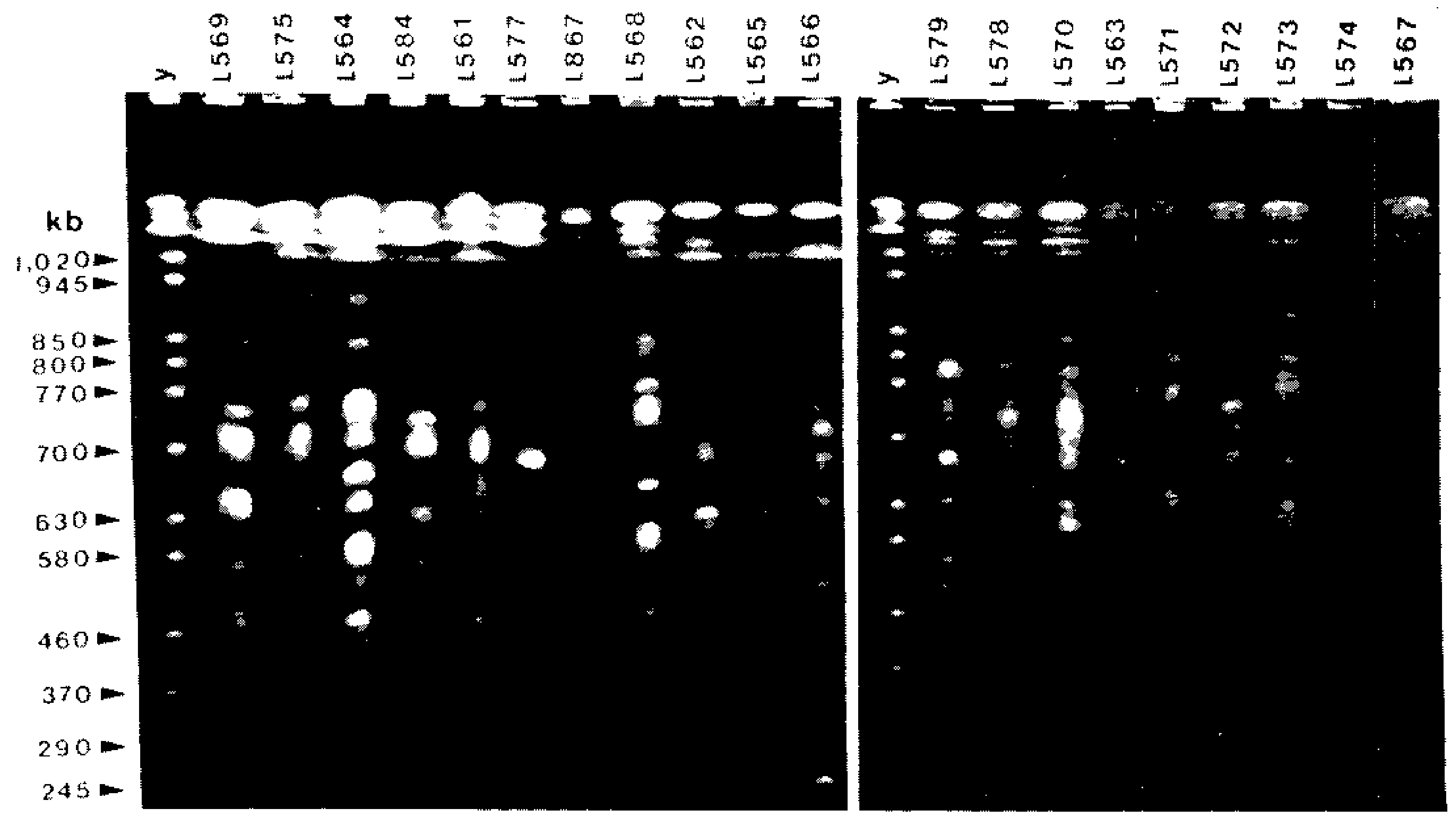

Fig. 2: CHEF electrophoresis separation of chromosome-sized DNA molecules under 1,000 kb from reference strains of species complexes of Leishmania. These $1.5 \%$ agarose gels were run at $175 \mathrm{~V}$ with a $100-50 \mathrm{~s}$ pulse ramp, for $40 \mathrm{hr}$ (using a CHEF DRII System from BioRad). The stock codes of the Leishmania strains analyzed are indicated above the lanes, and their origins are shown in the Table. 


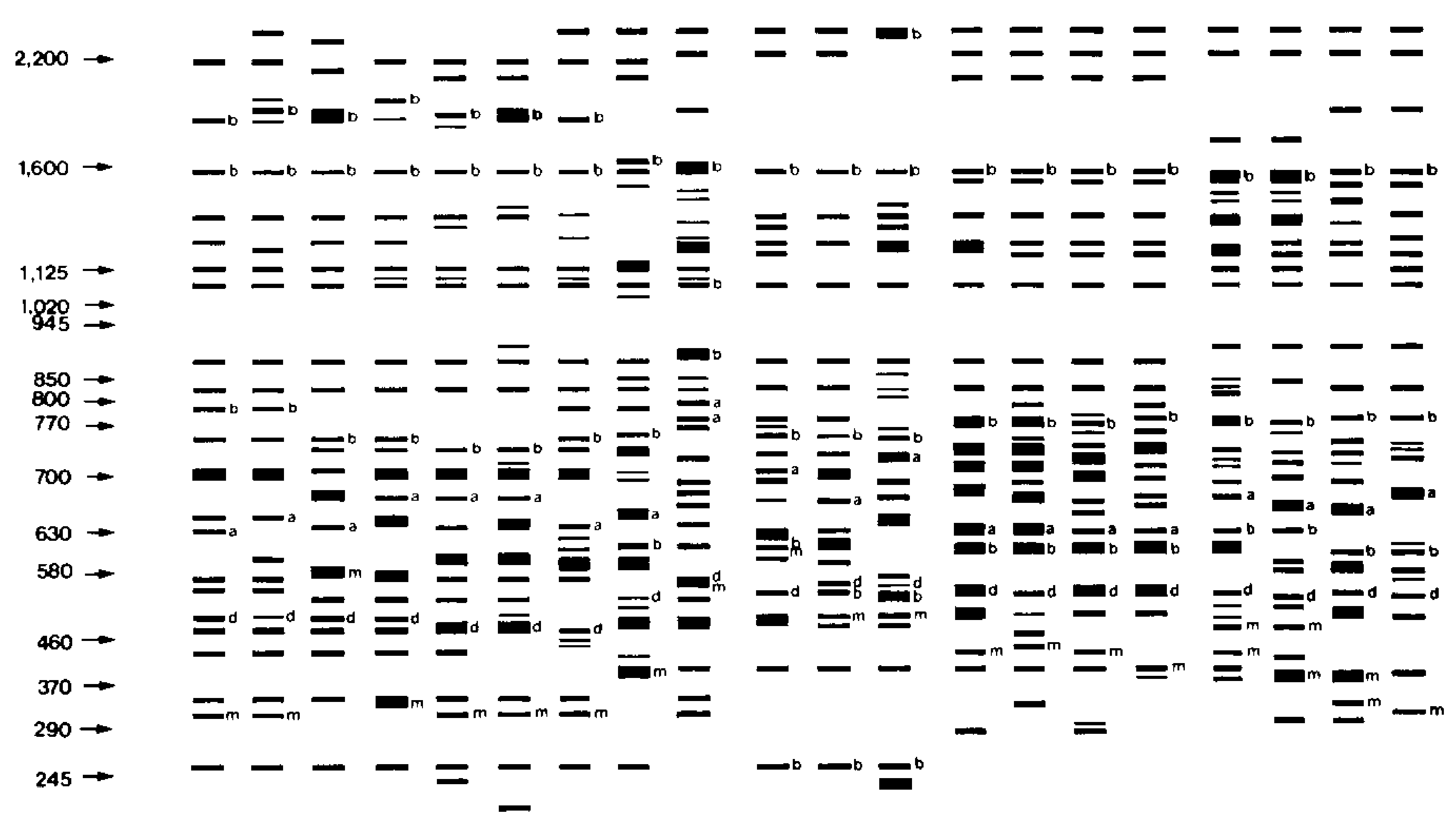

Fig. 3: diagrammatic representation of the karyotypes of 20 reference strains of species complexes of Leishmania, based on what is seen on several gels. The stock codes of the Leishmania strains analyzed are indicated above the lanes, and their origins are shown in the Table. The $245-2,200 \mathrm{~kb}$ scale at the left of the figure is drawn from yeast chromosome-sized DNA molecules. The location of the housekeeping genes on chromosomes is indicated as: $a=$ alpha-tubulin; $b=$ beta-tubulin; $m=$ mini-exon; and $d=$ DHFR-TS. 
TABLE

Origin and identification of Leishmania reference strains which were characterized by molecular karyotype analysis in this study

\begin{tabular}{|c|c|c|c|c|}
\hline $\begin{array}{l}\text { Stock } \\
\text { code }\end{array}$ & $\begin{array}{c}\text { Stock } \\
\text { designation }\end{array}$ & $\begin{array}{l}\text { Clinical } \\
\text { form } b\end{array}$ & $\begin{array}{c}\text { Geographic } \\
\text { origin }\end{array}$ & Species \\
\hline L56 1 & $\mathrm{MHOM} / \mathrm{BZ} / 82 / \mathrm{BEL} 21$ & CL & Belize, Belize & $L$ mexicana \\
\hline L562 & MHOM/PA/71/LS94 & CL & Canal Zone, Panama & L. panamensis \\
\hline L563 & MHOM/ET/67/L82 & VL & Humeria, Ethiopia & L. donovani s.l. \\
\hline L564 & MORY/PA/68/GML \# & VL & Darien, Panama & L. aristidesi \\
\hline L565 & MHOM/BR/75/M4147 & $\mathrm{CL}$ & Pará, Brazil & L. guyanensis \\
\hline L566 & MHOM/BR/75/M2903 & $\mathrm{CL}$ & Pará, Brazil & L. braziliensis \\
\hline L567 & $\mathrm{MCAV} / \mathrm{BR} / 45 / \mathrm{L} 88$ & $C L$ & Paraná, Brazil & $L_{n}$ enriettii \\
\hline L568 & MHOM/VE/74/PM-H3 & $\mathrm{CL}$ & Lara, Venezuela & L. venezuelensis \\
\hline L569 & MHOM/BR/73/M2269 & $\mathrm{CL}$ & Pará, Brazil & L. amazonensis \\
\hline L570 & $\mathrm{MHOM} / \mathrm{IN} / 80 / \mathrm{DD} 8$ & VL & Bihar, India & L. donovani \\
\hline L571 & $\mathrm{MHOM} / \mathrm{SU} / 58 / \mathrm{str}$. OD & $\mathrm{CL}$ & Azerbaijan, USSR & L. tropica \\
\hline L572 & $\mathrm{MHOM} / \mathrm{SU} / 74 / \mathrm{K} 27$ & CL & Azerbaijan, USSR & L. tropica \\
\hline L573 & MHOM/IL/67/Jer. II & CL & Jericho, Israel & L. major \\
\hline L574 & MRHO/SU59/nEAL P & $\mathrm{CL}$ & Uzbekistan, USSR & $L$ major \\
\hline L575 & IFLA/BR/67/PH8 & - & Pará, Brazil & L. amazonensis \\
\hline L577 & MNYC/BZ/62/M379 & CL & Cayo, Belize & $L$ mexicana \\
\hline L578 & MHOM/TN/80/IPT1 & VL & Monastir, Tunisia & L. infantum \\
\hline 1579 & MHOM/BR/74/PP75 & VL & Bahia, Brazil & L. chagasi \\
\hline L584 & MHOM/VE/76/JAP78 & $\mathrm{CL}$ & Merida, Venezuela & L. garnhami \\
\hline L867 & MHOM/VE/60/LtRod ${ }^{c}$ & DCL & Venezuela & L. pifanoi \\
\hline
\end{tabular}

a: code $:$ Host $(\mathrm{M}=$ Mammalia: $\mathrm{CAV}=$ Cavia porcellus; HOM = Homo sapiens; $\mathrm{NYC}=$ Nyctomys sumichrasti; $\mathrm{ORY}=$ Oryzomys capito $;$ and $\mathrm{RHO}=$ Rhombomys sp.; $\mathrm{I}=$ Insecta $; \mathrm{FLA}=$ Lutzomyia flaviscutellata $) /$ country of origin/year of isolation/original code.

$b: C L=$ cutaneous leishmaniasis $; \mathrm{DCL}=$ diffuse cutaneous leishmaniasis $;$ and $\mathrm{VL}=$ visceral leishmaniasis.

$c$ : as this strain was found to be phenotypically similar to reference strains of $L$. major it has also been named as

"L. major-like" (Hashiguchi et al., 1991).

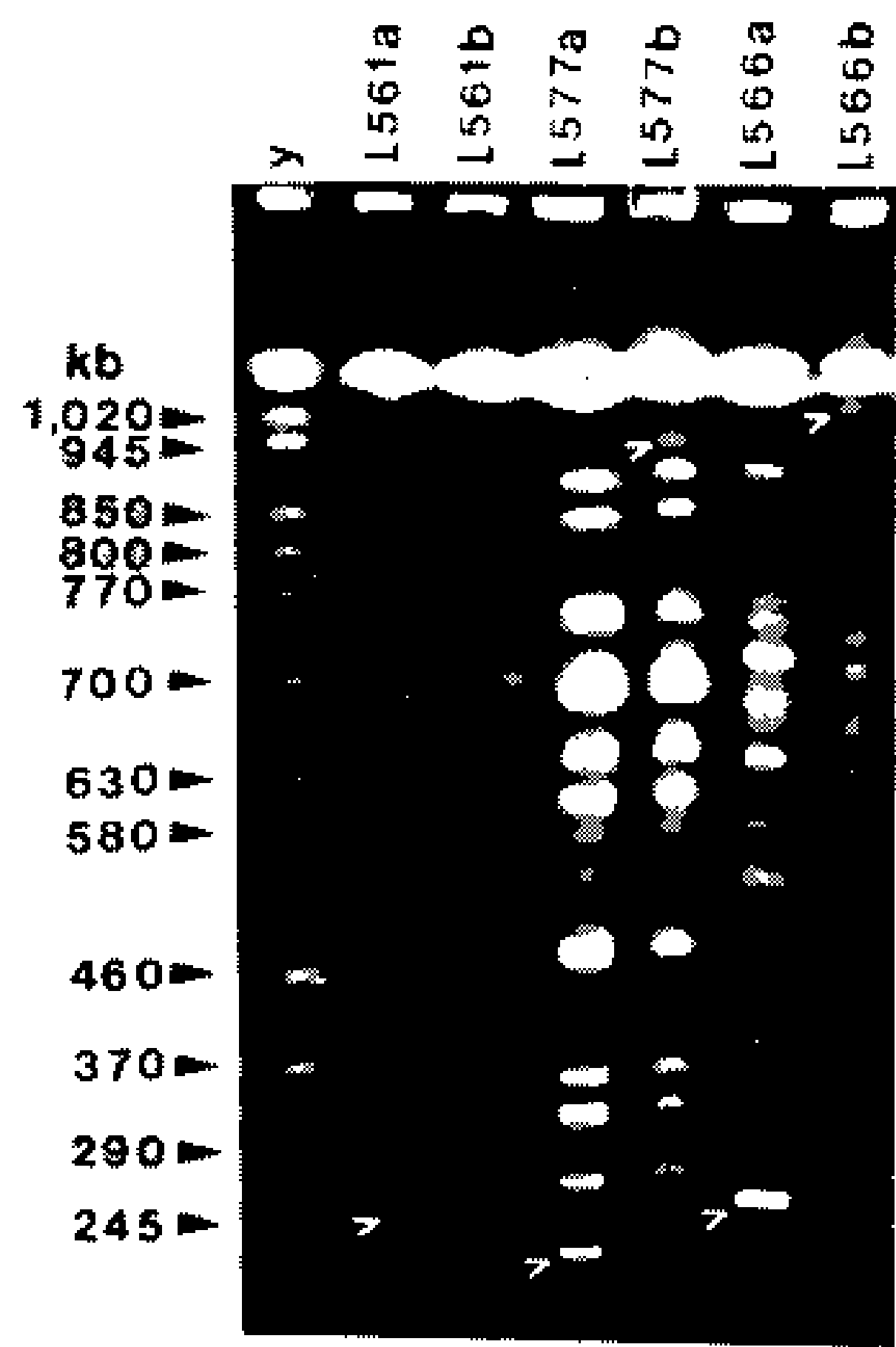

Fig. 4: occurrence (arrowheads) and disappearance of large and small linear DNAs in distinct stocks* of cloned $L$. braziliensis and $L$. mexicana reference strains. Chromosomes from the indicated stocks (see Table for their origins) were resolved by CHEF electrophoresis, using $1.5 \%$ agarose gels $(170 \mathrm{~V}$, pulse times of $120 \mathrm{~s}$ for $3 \mathrm{hr}, 90$ $\mathrm{s}$ for $30 \mathrm{hr}$ and $60 \mathrm{~s}$ for $15 \mathrm{hr}$ ), using a Pulsaphor electrophoresis unit from Pharmacia-LKB. Molecular weights are indicated in $\mathbf{k b}$ at the left of the figure. ${ }^{*}$ Stocks L56 Ib, L577a and L566b were kincly provided by Dr D. MacMahon-Pratt, Yale University School of Medicine. tion of chromosomal bands in the high size range was achieved using $1.0 \%$ agarose gels which were run with a $200-100 \mathrm{sec}$ pulse ramp, for $24 \mathrm{hr}$. This procedure allowed the fractionation of DNA molecules from $1,020 \mathrm{~kb}$ to at least $2,500 \mathrm{~kb}$ pairs in size. As at this long pulse time smaller molecules $(<1,020) \mathrm{mi-}$ grate with the same apparent $M$. W. due to reptation (Van der Ploeg et al., 1984), these molecules appeared compressed. However, optimal size separation of DNA molecules of M. W. under 1,000 kb (Fig. 2) was obtained using $1.5 \%$ agarose gels which were run with a $100-50 \mathrm{sec}$ pulse ramp, for $40 \mathrm{hr}$. This procedure did not allow the fractionation of chromosome-sized DNA larger than $1,000 \mathrm{~kb}$, thus giving rise to the compression zone shown at the top of the gel.

Based on results as those shown on Figs 1, 2 , we have constructed a diagrammatic representation (Fig. 3) of the total molecular karyotype for each reference strains of the Leishmania complexes species. A high proportion (approximately, three-fifths) of the chromosomes of parasites within the genus Leishmania ranges between 300 and $950 \mathrm{~kb}$ in size, and two bands 


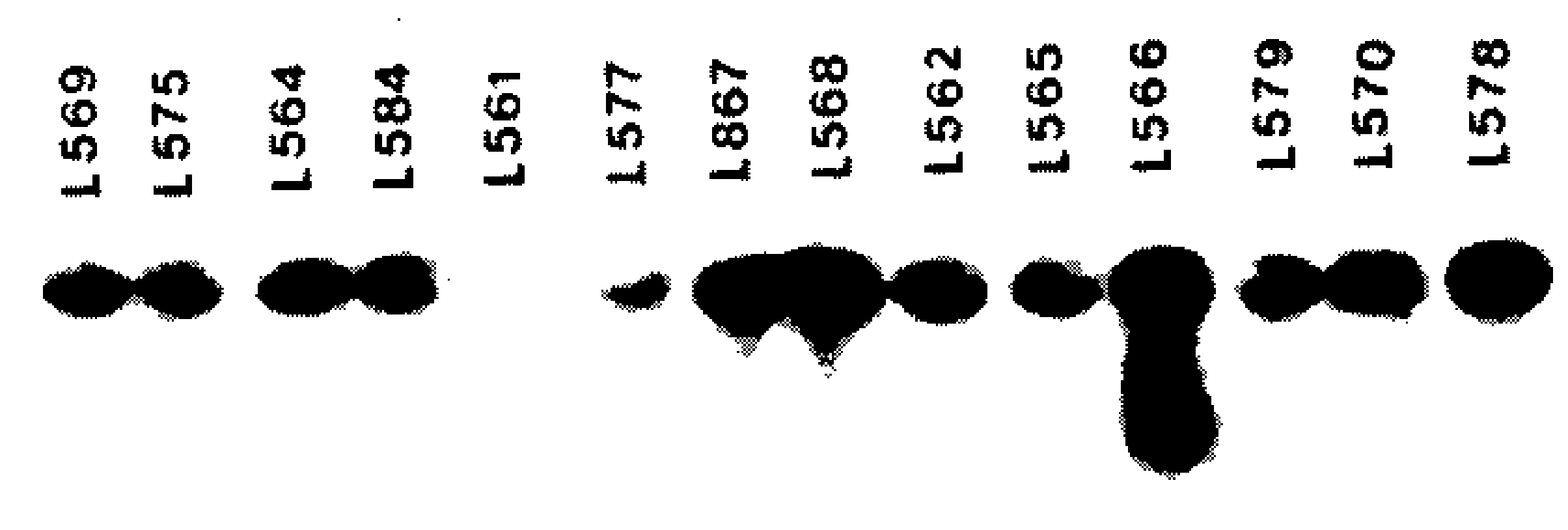

$245=$

A

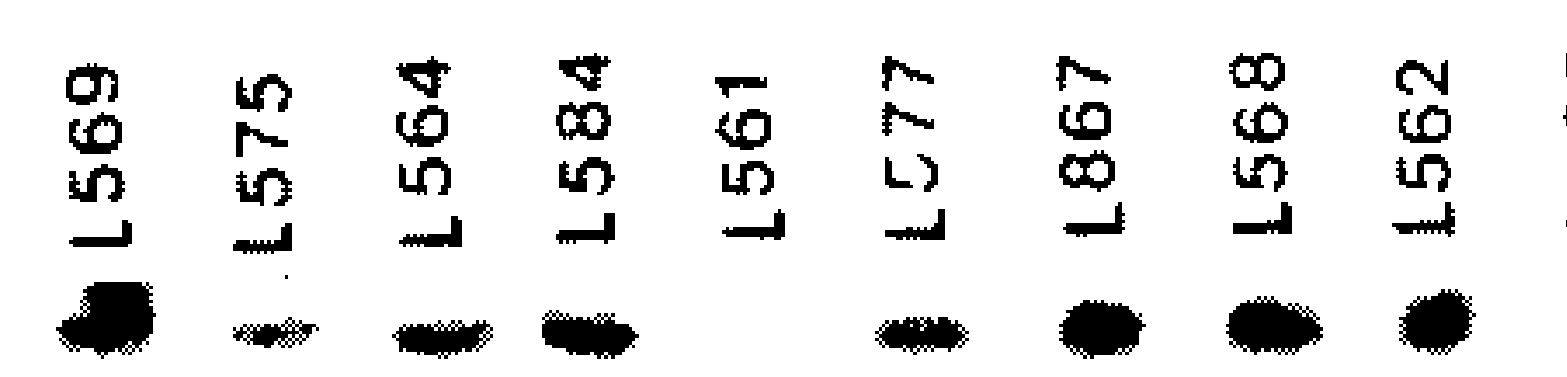

$\mathrm{kb}$

$850=$

$770=$

700

$630-$

$580 \mathrm{~m}$

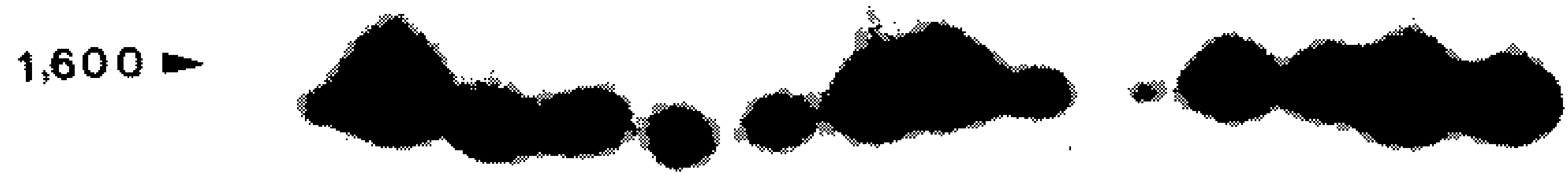

1,125

$700=$

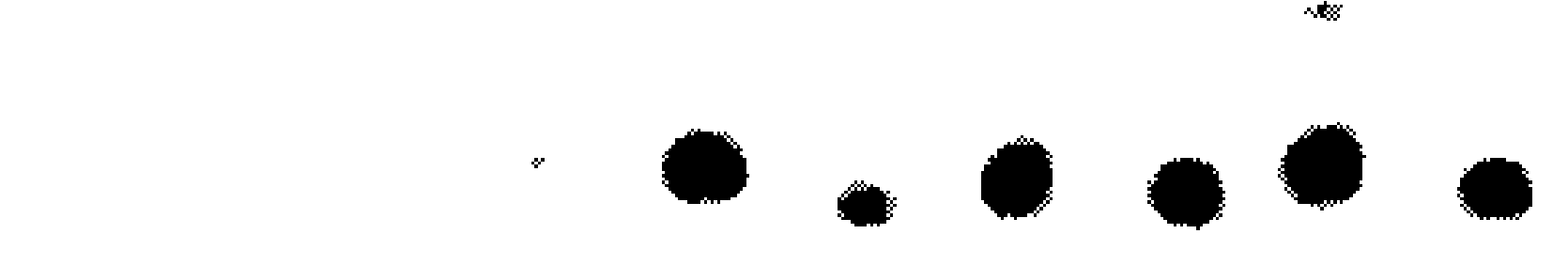

2,200<smiles>C1CCCCCC1</smiles>

B

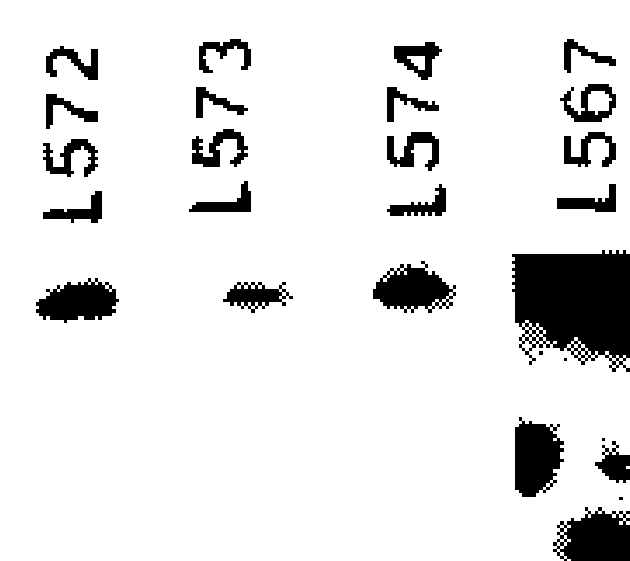

C

Fig. 5: autoradiograms after Southern hybridization of $32 \mathrm{p}$-labelled specific probes for the locations of beta-tubulin (A) and alpha-tubulin (B, C) genes to chromosomes of selected species complexes of Leishmania. Chromosomesized DNA molecules from the indicated stocks (see Table for their origins) were resolved by CHEF electrophorcsis, using the same running conditions as those in legend to Fig. 1 (A) or Fig. 2 (B and C).

of 1,600 and $1,050 \mathrm{~kb}$ in size were common in all stocks.

As shown in Fig. 4, comparison between stocks of the same cloned strain, but obtained from different laboratories, showed karyotype changes as revealed by the appearance/disappearance of small DNA molecules $(<245 \mathrm{~kb})$. In addition, in both L577b and L566b strains, in which the small DNAs were missing, it was 


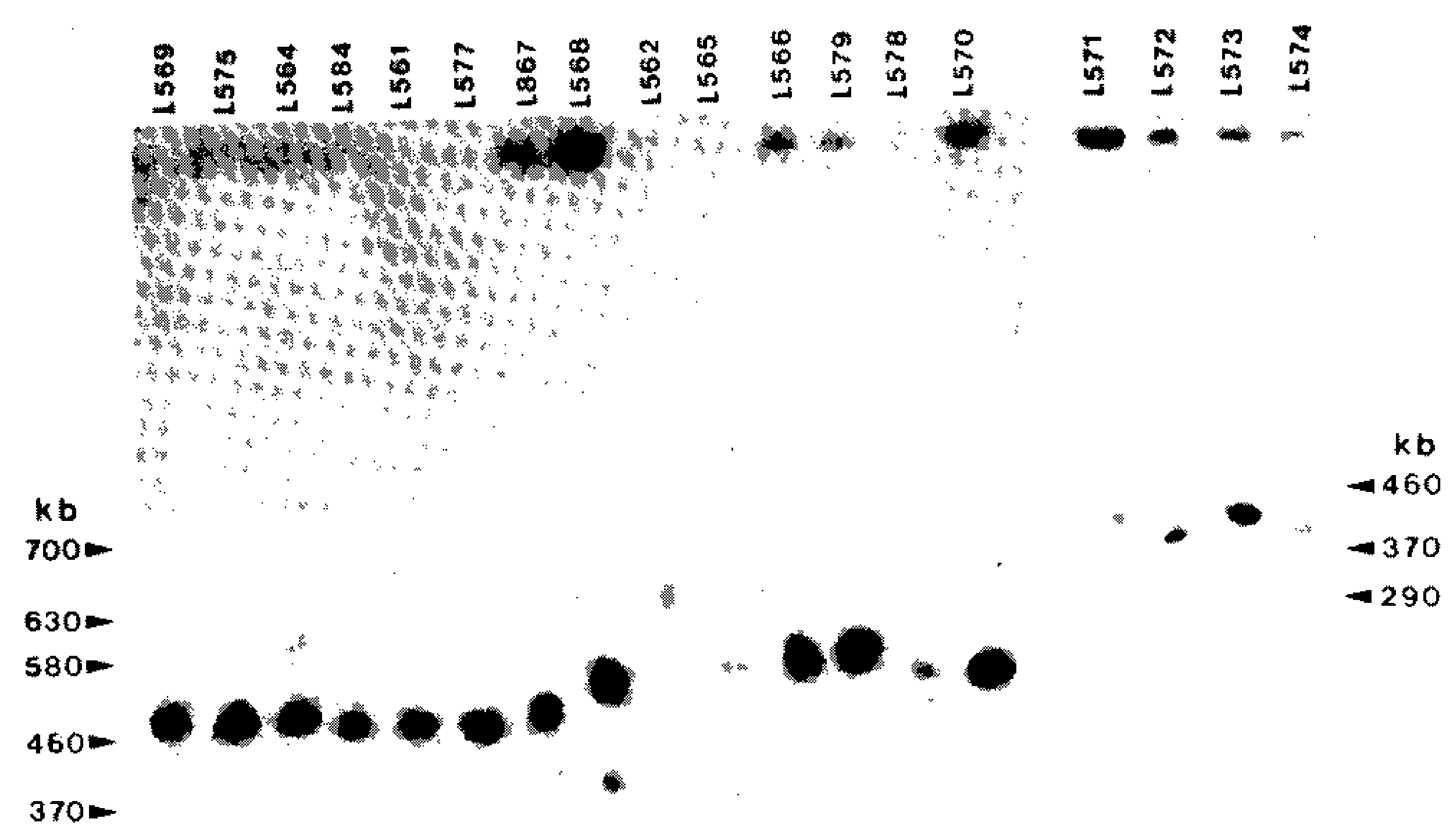

A

B
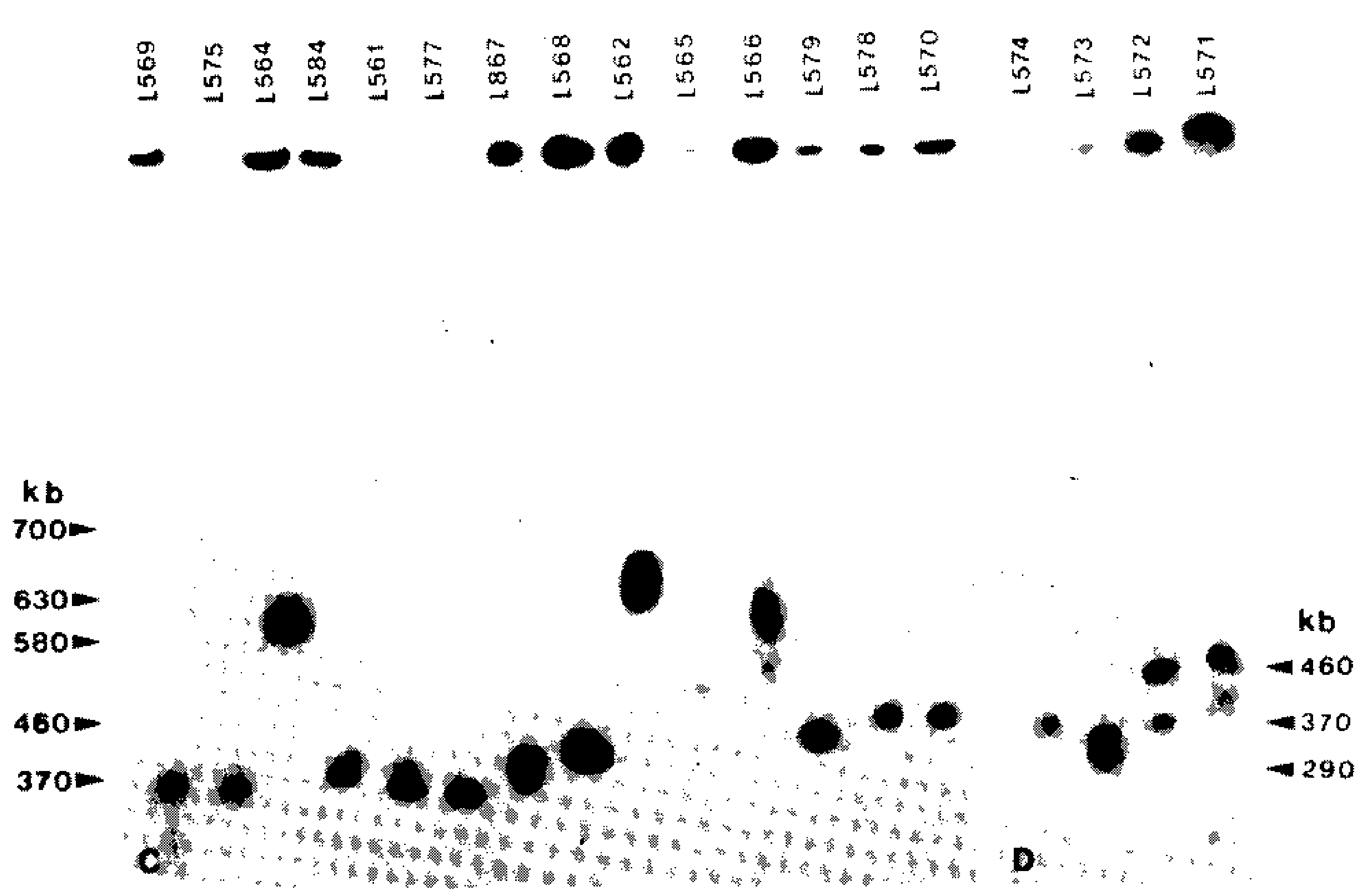

Fig. 6: chromosome location of DHFR-TS and mini-exon genes. Chromosome-sized DNA molecules derived from the indicated stocks were separated by CHEF electrophoresis, blotted to nylon membrane and probed with the DHFR-TS gene (A, B) and mini-exon gene (C, D) specific probes. The running conditions for the gels were as those described in legend to Fig. 2.

demonstrated an extra chromosomal band of approximately $900 \mathrm{~kb}$ and $1000 \mathrm{~kb}$ in size, respectively, that might represent a translocation.
Comparison of karyotypes among/within complexes of Leishmania - As shown in Fig. 3 , a total of 22-30 chromosomal DNA bands ranging in size between 200 and $2,500 \mathrm{~kb}$ were 
resolved, depending on the strain of Leishmania. Polymorphisms were most apparent among the DNA molecules in the low size range, but karyotypic differences among species complexes of Leishmania were more evident at the higher molecular weight zone $(1,000-2,500 \mathrm{~kb})$. Unique chromosome banding pattern was obtained for each reference strain, based on both the size of specific chromosomes and the overall pattern of ethidium bromide staining. Similarities in the karyotypes of members of the same Leishmania complex were great enough to distinguish them from the other groups. For instance, strains of the L. braziliensis complex could be distinguished by the characteristic absence of any chromosome band ranging in size between 1,600 and 2,200 kb in this group. Parasites of the $L$. donovani complex also showed a group-specific polymorphism of chromosomes at the M.W. range between 650 and $800 \mathrm{~kb}$. Chromosomes larger than this have a size homology close to $100 \%$. In contrast, although only reference strains were examined, the inter- and intraspecific variability in the number/size of DNA bands were not always clear enough to distinguish parasites within a given species group (Figs 1-3).

Chromosomal DNA locations of housekeeping genes - The chromosomal locations of genes for beta-tubulin, alpha-tubulin, DHFRTS and mini-exon are shown in Figs 3, 5, 6. The gene probles hybridized with several chromosomal bands ranging in size between 250 and $2,500 \mathrm{~kb}$. Whereas the sequences for betatubulin genes were located on chromosomes of similar sizes among Old World species complexes of Leishmania, clear differences in their locations were apparent in the New World Leishmania species (Figs 3, 5a) where hybridization was found in three to five bands. The alpha-tubulin genes were localized to a single band in all species with the exception of $L$. enriettii (Figs 3, 5b, c). The DHFR-TS and mini-exon genes were generally found on single chromosomal bands, ranging from 290 to 580 $\mathrm{kb}$ among distantly related groups (Figs 3,6 ). However, the mini-exon genes were localized in two bands of varying size in strains from both the $L$. tropica and $L$. major complexes (Fig. 6d).

\section{DISCUSSION}

Previous studies revealed distinctive molecular karyotypes when Leishmania stocks from either the Old or New World were analyzed by PFGE (Giannini et a1., 1986; Scholler et al., 1986; Bishop \& Miles, 1987; Samaras \& Spithill, 1987; Dujardin et al., 1989). Chromosome polymorphisms occur in Leishmania such that each strain or clone of a given species has a unique karyotype (Pagès et al., 1989; Bastien et al., 1990). Indeed, this technique has been used for typing unidentified clinical isolates by comparison with Leishmania reference strains (Giannini et al., 1986; Dujardin et al., 1989). Confirming previous data (Scholler et al., 1986; Giannini et al., 1990), our analysis showed that significant karyotype concordances were found among closely related strains than among more distantly related groups. As a possible exception, we should refer to the apparent poor karyotypic relationship between $L$. enriettii and the other species within the L. mexicana group (Fig. 3). However, distinct relationships of this parasite and other members of the genus Leishmania have been demonstrated, as revealed by quantitative comparisons of nuclear DNA fragment patterns (Beverley et al., 1987), which correspond to those predicted from previous molecular and taxonomic studies using isoenzymes and specific monoclonal antibodies (Momen \& Grimaldi, unpublished data). In contrast, clear distinction among parasites within a given species group was generally less evident. For instance, on the basis of the observed molecular karyotypes the $L$. amazonensis strains were as distinct to one another as they were to some other species of the L. mexicana complex. This finding suggests that molecular karyotyping is good for classifying Leishmania stocks as a group but its potential usefulness for identifying the parasite species in field surveys is less clear. However, the method still remains to be tested in large and geographically widespread epidemiologic and taxonomic studies before any conclusion can be drawn on this matter. Work is in progress in our laboratories to better evaluate the natural variation of these molecular markers under different conditions by examining Leishmania isolates from distinct endemic foci in widely separated geographic areas.

As described previously in L. braziliensis (Scholler et al., 1986), L. mexicana (Samaras \& Spithill, 1987), L. donovani (Bishop \& Miles, 1987) and L. major (Beverley \& Coburn, 1990), we also observed the appearance of a small chromosome band in each karyotype of the two first species. Its greater intensity compared to the other DNA bands suggests a higher copy number (Scholler et al., 1986; Beverley \& Co- 
burn, 1990). It may represent replicating circular DNAs of episomal or viral origin, appearing as either an anomalously small band or integrated into one of the DNA chromosomal bands of the Leishmania (Gajendran et al., 1989; Hamers et al., 1989; Stuart et al., 1989). Alternatively, recurrent emergence of new small linear chromosomes (ranging in size from 180 to $220 \mathrm{~kb}$ ) may occur in Leishmania, either spontaneously during routine serial passage in vitro or under methotrexate pressure (Beverley \& Coburn, 1990). The possibility of the L577 strain being exposed to anti-leishmanial drugs prior to establishment in vitro seems unlikely, given the fact that it was isolated from wild reservoir host. Assuming that this as well as the other stocks analyzed in this study have not been exposed to any experimental drug pressure, the small chromosomes may have emerged spontaneously. Work is now in progress to better define the relationship between these small DNA molecules and those previously described.

Our results are generally consistent with previous data (Spithill \& Samaras, 1985; 1987; Comeau et al., 1986; Giannini et al., 1986; Scholer et al., 1986; Samaras \& Spithill, 1987; Dujardin et al., 1989) on the chromosomal locations of housekeeping genes among different species of Leishmania. It is possible that the discrepancy existing in the hybridization patterns of some gene probes obtained in this study and those from other reports is due to either strain variation or different running conditions. Relative mobilities of chromosomesized DNA molecules can be considerably affected by several parameters for separation (e. g., different voltage and pulse frequency, temperature and ionic strenght of the electrophoresis buffer, and type or concentration of agarose) (Van der Ploeg et al., 1984). As the beta-tubulin genes were found on different chromosome size classes, showing some group- or species-specific variations of hybridization patterns, we concluded that these molecular markers may also be useful for parasite classification.

\section{ACKNOWLEDGEMENTS}

To Dr Diane McMahon-Pratt for the use of laboratory facilities at Yale University for the development of part of this work.

\section{REFERENCES}

ANONYMOUS, 1984. The Leishmaniases, WHO Techn. Rep. Ser. No. 70I, Geneva, 140 p.
ANONYMOUS, 1990. Control of the leishmaniases. WHO Techn. Rep. Ser. No. 793, Geneva, 158 p.

BASTIEN, P.; BLAINEAU, C.; TAMINH, M.; RIOUX, J. A.; ROIZES, G. \& PAGES, M., 1990. Interclonal variations in molecular karyotype in Leishmania infantum imply a 'mosaic' strain structure. Mol. Biochem. Parasitol., 40: 53-62.

BEVERLEY, S. M. \& COBURN, C. M., 1990. Recurrent de novo appearance of small linear DNAs in Leishmania major and relationship to extra-chromosomal DNAs in other species. Mol. Biochem. Parasitol, 42: 133-142.

BEVERLEY, S. M.; CODERRE, J. A.; SANTl, D. V. \& SCHIMKE, R. T., 1984. Unstable DNA amplification in methotrexate-resistant Leishmania consist of extrachromosomal circles which relocalize during stabilization. Cell, 38: 431-439.

BEVERLEY, S. M.; ISMACH, R. B. \& MCMAHONPRATT, D., 1987. Evolution of the genus Leishmania as revealed by comparisons of nuclear DNA restriction fragment patterns. Proc. Natl Acad. Sci. (USA), 84: 484-488.

BISHOP, R. P. \& MILES, M. A., 1987. Chromosome size polymorphisms of Leishmania donovani. Mol. Biochem. Parasitol., 24: 263-272.

CARLE, G. F. \& OLSON, M. V., 1984. Separation of chromosomal DNA molecules from yeast by orthogonal-field alternation gel electrophoresis. Nucleic Acids Res., 12: 5647-5664.

CHU, G.; VOLLRATH, D. \& DAVIS, R W., 1986. Separation of large DNA molecules by contourclamped homogeneous electric fields. Science, 234 . 1582-1585.

COMEAU, A. M.; MILLER, S. I. \& WIRTH, D. F., 1986. Chromosome location of four genes in Leish mania. Mol. Biochem. Parasitol., 21: 161-169.

DUJARDIN, J. C.; GAJENDRAN, N.; HAMERS, R.; MATTHIJSEN, G.; URJEL, R.; RECACOECHEA, M.; VILLARROEL, G.; BERMUDEZ, H.; DESJEUX, P.; DE DONCKER, S. \& LE RAY, D., 1989. Leishmaniasis in the lowlands of Bolivia (Leishbol): Part VIII. Characterization and identification of Bolivian isolates by PFG karyotyping, p. 137-148. In D. T. Hart, Leishmaniasis: The Current Status and New Strategies for Control. Plenum Press, New York.

FEINBERG, A. P. \& VOGELSTEIN, B., 1983. A technique for radiolabelling DNA restriction endonuclease fragments to high specific activity. Anal. Biochem., 132: 6-13.

GAJENDRAN, N.; DUJARDIN, J. -C.; LE RAY, D. \& MATTHYSSENS, G. 1989. Abnormally migrating chromosome identifies Leishmania donovani populations, p. 539-547. In D. T. Hart, Leishmaniasis: The Current Status and New Strategies for Control. Plenum Press, New York.

GIANNINI, S. H.; CURRY, S. S.; TESH, R. B. \& VAN DER PLOEG, L. H. T., 1990. Size-conserved chromosomes and stability of molecular karyotype in cloned stocks of Leishmania major. Mol. Biochem. Parasitol., 39: 9-22.

GIANNINI, S. H.; SCHITTINI, M.; KEITHLY, J. S.; WARBURTON, P. W.; CANTOR, C. R. \& VAN DER PLOEG, L. H. T., 1986. Karyotype analysis of Leishmania species and its use in classification and clinical diagnosis. Science, 232: 762-765. 
GRIMALDI, JR., G.; TESH, R. B. \& MCMAHONPRATT, D., 1989. A review of the geographic distribution and epidemiology of leishmaniasis in the New World. Am. J. Trop. Med. Hyg., 4l: 687-725.

HAMERS, R.; GAJENDRAN, N.; DUJARDIN, J. C. \& STUART, K, 1989. Circular and linear forms of small nucleic acids in Leishmania, p. 985-988. In D. T. Hart, Leishmaniasis: The Current Status and New Strategies for Control. Plenum Press, New York.

HASHIGUSHI, Y.; GOMEZ, E. A.; DE CORONEL, V. V.; MIMORI, T.; KAWABATA, M.; FURUYA, M.; NONAKA, S.; TAKAOKA, H.; BRUCE ALEXANDER, J.; QUIZHPE, A. M.; GRIMALDI, JR., G.; KREUTZER, R. D. \& TESH, R. B., 1991. Andean leishmaniasis in Ecuador caused by infection with Leishmania mexicana and $L$. major-like parasites. Am. J. Trop. Med. Hyg., 44: 205-217.

HENDRICKS, L. D.; WOOD, D. E. \& HADJUK, M. E., 1978. Haemoflagellated commercially available liquid media for rapid cultivation. Parasitology, 76: 309-316.

IOVANNISCI, D. M. \& BEVERLEY, S. M., 1989. Structural alterations of chromosome 2 in Leishmania major as evidence for diploidy, including spontaneous amplifications of the miniexon array. $\mathrm{Mol}$. Biochem. Parasitol, 34: 177-188.

LAINSON, R. \& SHAW, J. J., 1987. Evolution, classification and geographical distribution, p. 1-120. In W. Peters \& R. Killick-Kendrick (eds), The Leishmaniasis in Biology and Epidemiology, Volume I. Acad. Press, London.

MANIATIS, T.; FRITISCH, E. \& SAMBROOK, J., 1982. Molecular Cloning, A Laboratory Manual. Cold Spring Harbor Laboratory, Cold Spring Harbor, New York.

PAGES, M.; BASTEIN, P.; VEAS, F.; ROSSI, V.; BELLIS, M.; WINCKER, P.; RIOUX, J. -A. \& ROIZES, G., 1989. Chromosome size and number polymorphisms in Leishmania infantum suggest amplification/deletion and possible genetic ex- change. Mol. Biochem. Parasitol, 36: 161-168.

RIOUX, J. -A., 1986. Leishmania. Taxonomy and Phylogeny, p. 537. IMEEE, Montpellicr.

SAMARAS, N. \& SPITHILL, T. W., 1987. Molecular karyotype of five species of Leishmania and analysis of gene locations and chromosomal rearrangements. Mol. Biochem. Parasitol, 25: 279-291.

SCHOLLER, J. K. REED, S. \& STUART, K., 1986. Molecular karyotype of species and subspecies of Leishmania. Mol. Biochem. Parasitol., 20: 279-293.

SCHWARTZ, D. C. \& CANTOR, C. R., 1984. Separation of yeast chromosome sized DNAs by pulsed field gradient gel electrophoresis. Cell, 37: 67-75.

SPITIILL, T. W. \& SAMARAS, N., 1985. The molecular karyotype of Leishmania major and mapping of alpha and beta tubulin gene families to multiple unlinked chromosomal loci. Nucleic Acids Res., 13: 4155-4169.

SPITHILL, T. W. \& SAMARAS, N., 1987. Chromosome size polymorphisms and mapping of tubulin gene loci in Leishmania, p. 269-278. In N. Agabian; H. Goodman \& N. Nogueira (eds), Molecular Strategies of Parasitic Invasion. UCLA Symposia on Molecular and Cellular Biology, New Series, Vol. 42. Alan R. Liss, Inc., New York.

STUART, K.; TARR, P.; ALINE JR., R.; SMJLEY, B.; SCHOLLER, J. \& KEITHLY, J., 1989. Small nucleic acids in Leishmania, p. 917-923. In D. H. Hart, Leishmaniasis: The Current Status and New Strategies for Control. Plenum Press, New York.

TAKEUCHI, A. M. \& TRAUB-CSEKO, Y. M., 1991. Development of nuclear DNA probes for the typing of Trypanosoma cruzi. Mem. Inst. Oswaldo Cruz, 86: 307-315.

VAN DER PLOEG, L. H. T.; CORNELISEN, A. W. C. A.; BARRY, J. D. \& BORST, P., 1984. The chromosomes of the kinetoplatids. EMBO J., 3: 3109 3115.

WIRTH, D. F. \& SLATER, C., 1983. Isolation and characterization of an alfa-tubulin gene from Leishmania enriettii. Mol. Biochem. Parasitol., 9: 83-92. 